\title{
The human skin as a hormone target and an endocrine gland
}

\author{
Christos C. Zouboulis
}

Department of Dermatology, Charité University Medicine Berlin, Campus Benjamin Franklin, Berlin, Germany

\begin{abstract}
Hormones influence the development and function of human skin which also produces and releases hormones. Recently attention has been focused on identifying and understanding the complex endocrine properties of human skin, such as expression and function of specific hormone receptors, synthesis of hormones from major classes of compounds used by the body for general purposes, organized metabolism, activation, inactivation and elimination of the hormones in specialized cells of the tissue, exertion of biological activity and release of tissue hormones in the circulation. Specifically, hormones exert their biological effects on the skin through interaction with high-affinity receptors, such as several receptors for peptide hormones and neurotransmitters, steroid and thyroid hormones. Hormones exhibit a wide range of biological activities on the skin with distinct effects caused by growth hormone/insulin-like growth factor-I, neuropeptides, sex steroids, glucocorticoids, retinoids, vitamin $\mathrm{D}$, peroxisome proliferator-activated receptor ligands, eicosanoids, melatonin and serotonin. Human skin produces, activates or inactivates metabolically numerous hormones which are probably important for skin functions but also for functions of the entire human organism, such as sex hormones, especially in aged individuals, insulin-like growth factor and -binding proteins, neuropeptides, prolactin, catecholamines, retinoids, steroids, vitamin $D$ and eicosanoids. These functions are undertaken in most cases by different skin cell populations in a coordinated way, indicating the endocrine autonomy of the skin. Characteristic examples are the metabolic pathways of the corticotropin-releasing hormone/propiomelanocortin axis, steroidogenesis, vitamin $D$ and retinoids. The human skin is, thus, the largest, peripheral endocrine organ.
\end{abstract}

Key Words: Human skin, Endocrinology, Hormone synthesis, Hormone receptors, Hormone metabolism, Hormone activity

\section{INTRODUCTION}

The human skin is classically regarded as the target for several hormones whose effects have long been

Address correspondence and requests for reprints to:

Prof. Dr. Christos C. Zouboulis, Department of Dermatology,

Charité University Medicine Berlin, Campus Benjamin

Franklin, Fabeckstrasse 60-62, 14195 Berlin, Germany,

Tel.: +49-30-84456910, Fax: +49-30-84456908,

e-mail:zouboulis@medizin.fu-berlin.de

Received 29-08-03, Revised 17-10-03, Accepted 20-11-03 recognized and in some instances well characterized ${ }^{1}$. For example, hair follicles and sebaceous glands are the targets for androgen steroids secreted by the gonads and the adrenal cortex ${ }^{2,3}$ and melanocytes are directly influenced by polypeptide hormones of the pituitary ${ }^{4}$. In addition, hormones play an important role in the development and the physiological function of human skin tissues ${ }^{5,6}$. From the modern dermato-endocrinologic point of view, the skin is not only the recipient of signals from distant transmitters but is also an organized community in which the cells and 
organelles emit, receive and coordinate molecular signals from a seemingly unlimited number of distant sources, their neighbors and themselves ${ }^{7}$. In the widest sense, the human skin and its cells are the targets as well as the producers of hormones. For example, the circulating androgens dehydroepiandrosterone (DHEA) and androstenedione are converted in the skin to testosterone and further to 5a-dihydrotestosterone $(5 \mathrm{a}-\mathrm{DHT})^{3,8}$.

Despite this widely accepted knowledge, focus on the complex endocrine properties of the human skin has been directed only recently ${ }^{1,5,7}$. New data have rapidly accumulated in the last three years regarding expression and function of specific hormone receptors, synthesis of hormones from major classes of compounds used by the body for general purposes, organized metabolism, activation, inactivation and elimination of the hormones in specialized cells of the tis- sue, exertion of biological activity and release of hormones in the circulation, and these are included in this review.

\section{THE HUMAN SKIN AS HORMONE TARGET}

\section{Hormone Receptors}

Hormones exert their biological effects on the skin through binding and interaction with high-affinity receptors. The human skin expresses receptors for peptide hormones and neurotransmitters, which are mostly aligned on the cell surface, and for steroid and thyroid hormones, which are found in the cytoplasm or nuclear compartments (Figure 1).

Receptors for peptide hormones and neurotransmitters: Three of four groups of peptide hormone and neurotransmitter receptors are represented in human skin. The so-called serpentine or "seven transmem-

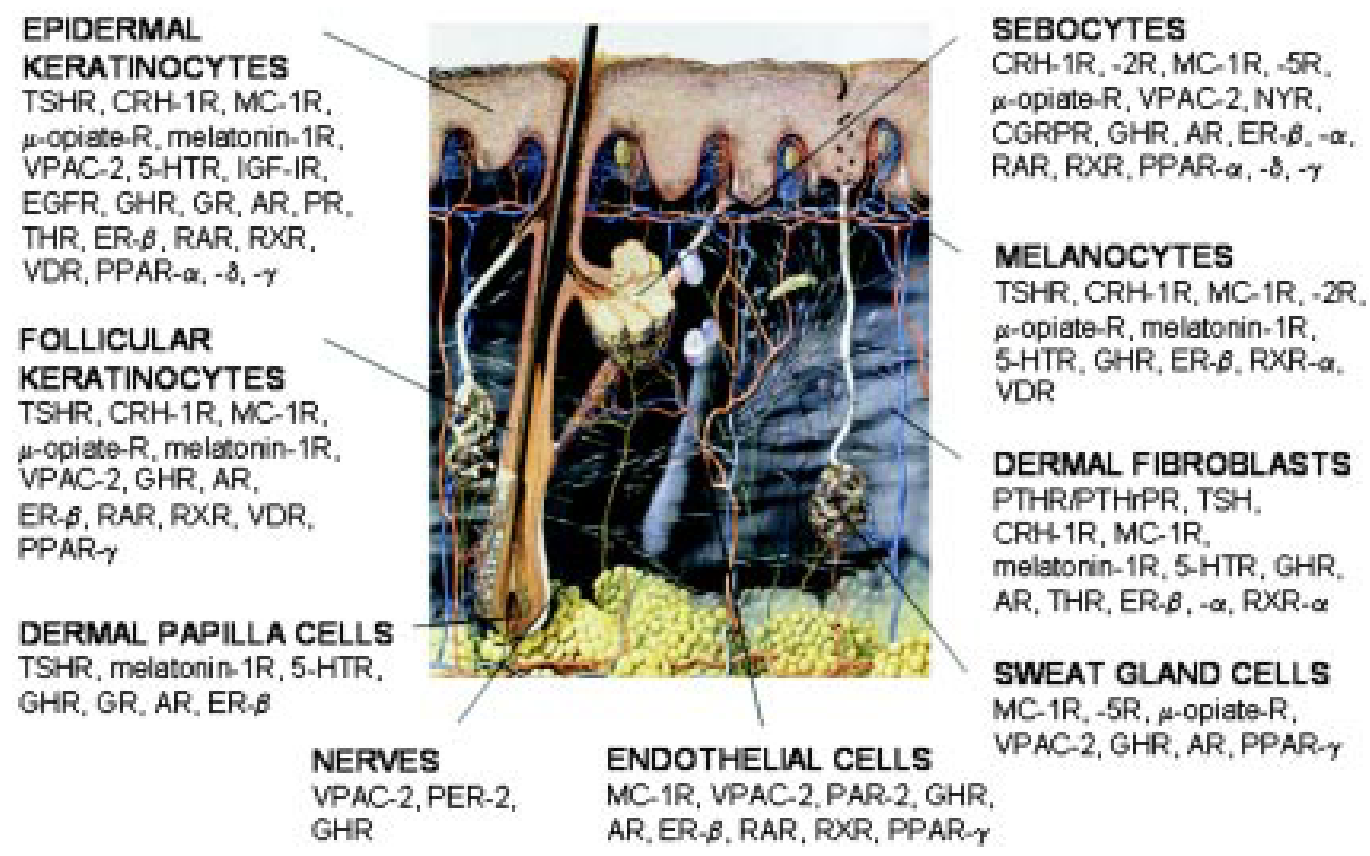

Figure 1. Hormone receptors detected as being active in human skin cells. PTHR/PTHrPR, parathyroid hormone receptor/parathyroid hormone-related peptide receptor; TSHR, thyroid-stimulating hormone receptor; CRH-1R, -2R, corticotropin-releasing hormone receptors types 1 and 2; MC-1R, -2R, -5R, melanocortin receptor types 1,2 and 5; $\mu$-opiate-R, $\mu$-opiate receptors; melatonin-1R, melatonin receptor type 1; VPAC-2, vasoactive intestinal popypeptide receptor type 2; NYR, neuropeptide Y receptor; CGRPR, calcitonin gene-related peptide receptor; 5-HTR, serotonin receptors (5-hydroxytryptamine receptors); PAR, proteinase-activated receptors; IGF-IR, insulin/insulin-like growth factor I receptor; GHR, growth hormone receptor; GR, glucocorticoid receptor; AR, androgen receptor; PR, progesterone receptor; THR, thyroid hormone receptors (isotypes a1 and b1); ER- $\beta$, - $\alpha$, estrogen receptor types $\beta$ and $\alpha$; RAR, retinoic acid receptors; RXR, retinoid X receptors; RXR- $\alpha$, retinoid X receptor type $\alpha$; VDR, vitamin D (calcitriol) receptor; PPAR- $\alpha,-\delta,-\gamma$, peroxisome proliferatorrelated receptors types $\alpha, \delta, \gamma$. 
brane domain" receptors contain an amino terminal extracellular domain followed by seven hydrophobic aminoacid segments, each of which spans the membrane bilayer. The seventh segment is followed by a hydrophilic carboxyl terminal domain, which resides within the cytoplasmic compartment. To this group belong:

a) the parathyroid hormone (PTH)/parathyroid hormone-related peptide (PTHrP) receptor which is expressed in dermal fibroblasts but not in epidermal keratinocytes $^{9,10}$;

b) the thyroid-stimulating hormone (TSH) receptor which is present in epidermal, follicular and neonatal keratinocytes, epidermal melanocytes and dermal and dermal papilla fibroblasts ${ }^{11}$;

c) the corticotropin-releasing hormone $(\mathrm{CRH})$ receptors from which type 1 is predominant in human skin, being present in epidermal and follicular keratinocytes, melanocytes and dermal fibroblasts, whereas sebocytes express types 1 and $2^{12,13}$;

d) the melanocortin receptors (MC), among them $\mathrm{MC1}$ which presents high affinity for a-melanocyte-stimulating hormone ( $\alpha$-MSH) and adrenocorticotropic hormone (ACTH) and is expressed in epidermal and follicular keratinocytes, epidermal and follicular melanocytes, sebocytes, sweat gland cells, endothelial cells, Langerhans cells, monocytes, macrophages, lymphocytes and dermal fibroblasts, MC2 which is specific for ACTH and is expressed in epidermal melanocytes and adipocytes, and MC5 which shows affinity for $\alpha-\mathrm{MSH}$ and ACTH and is present in sebocytes, sweat gland cells and adipocytes $^{12,14-17}$. MC5 but not MC1 expression can be enhanced after treatment of cultured sebocytes with $\alpha-\mathrm{MSH}^{17}$;

e) the $\mu$-opiate receptors which bind with high affinity $\beta$-endorphin and are expressed in epidermal and outer root sheath keratinocytes, melanocytes, sebocytes and cells of the sweat gland secretory por$\operatorname{tion}^{12,18,19}$;

f) the melatonin receptors type 1 , which is the predominant variant expressed in normal adult epidermal, follicular and neonatal keratinocytes, epidermal melanocytes, and in dermal and hair follicle papilla fibroblasts, and type 2 which has been detected only in neonatal keratinocytes ${ }^{20}$; g) the vasoactive intestinal popypeptide (VIP) receptors $(V P A C)$ which are expressed in epidermal keratinocytes, with VPAC2 exhibiting the most pronounced expression in keratinocytes of the basal layer and in glandular cells surrounded by VIPimmunoreactive nerve fibers, hair follicle cells next to VIP-positive fibers, sebocytes, sweat gland cells, endothelial cells, mononuclear cells and dermal nerve fibers ${ }^{21-24}$;

h) the neuropeptide Y receptor which is present in sebocytes $^{23}$;

i) the calcitonin gene-related peptide (CGRP) receptor which is expressed in sebocytes and Langerhans cells $^{23,25}$;

j) the serotonin receptors (5-hydroxytryptamine receptors, 5-HTR) which can be categorized into seven families (5HTR1-7) and include at least 21 subtypes $^{26}$. They are cation-selective transmitter-gated ion channels of the Cys-loop superfamily. 5HTR1A, 5HTR1B and 5HTR2A expression was detected in epidermal keratinocytes, melanocytes and dermal fibroblasts, whereas 5HTR2A is also expressed in dermal papilla fibroblasts. 5HTR2C mRNA message was found in follicular melanocytes, dermal papilla fibroblasts and dermal fibroblasts. The 5HTR2B and 5HTR7 variants were generally detected in normal $\operatorname{skin}^{20}$; and

k) the proteinase-activated receptors (PARs) represent a unique subclass of G-protein-coupled receptors of which four family members have now been cloned from a number of species ${ }^{27}$. The novel mechanism of receptor activation involves the proteolytic unmasking of a cryptic N-terminal receptor sequence that, remaining tethered, binds to and triggers receptor function. In addition, short (5-6 aminoacids) synthetic peptides, based on the proteolytically revealed motif can activate PARs without the unmasking of the tethered ligand. In the skin, PAR-2 is expressed on sensory neurons and endothelial cells and may have high impact in regulating cutaneous neurogenic inflammation ${ }^{28}$.

The second group includes insulin/insulin-like growth factor I (IGF-I) receptor and the epidermal growth factor (EGF) receptor which are expressed in epidermal keratinocytes ${ }^{29,30}$ and belong to the singletransmembrane domain receptors that harbor intrinsic tyrosine kinase activity. 
The third group, which is functionally similar to the second group, is characterized by a large extracellular binding domain followed by a single membrane spanning segment and a cytoplasmic tail. These receptors do not possess intrinsic tyrosine kinase activity but appear to function through interaction with soluble transducer molecules which do possess such activity. In human skin, they are represented by the growth hormone $(\mathrm{GH})$ receptor which is present in melanocytes and dermal fibroblasts, epidermal and follicular keratinocytes of the outer root sheath, especially the basal ones, sebocytes, cells of the sweat gland secretory duct, hair matrix cells of the dermal papillae, endothelial cells, Schwann cells of peripheral nerve fascicles and adipocytes of the dermis ${ }^{29,31,32}$.

Steroid hormone and thyroid hormone receptors: The nuclear receptors differ from the receptors of the cell membrane in that they are soluble molecules with a proclivity for employing transcriptional regulation as a means of promoting their biological effects. Thus, though some receptors are compartmentalized in the cytoplasm and others are confined to the nucleus, they all operate within the nucleus chromatin to initiate the signaling cascade. They associate in the nucleus with DNA sequences bearing a specific recognition element called "hormone response element". Hormone response elements have different canonical sequences for each hormone. These receptors are expressed in human skin and can be grouped into two major subtypes groups based on shared structural and functional properties.

The first group, the steroid receptor family, includes:

a) the glucocorticoid receptor which is mainly expressed in basal keratinocytes, Langerhans cells and dermal fibroblasts ${ }^{33,34}$;

b) the androgen receptor $(A R)$ which is present in epidermal and follicular keratinocytes, sebocytes, sweat gland cells, dermal papilla cells, dermal fibroblasts, endothelial cells and genital melanocytes $^{3,35-37}$; and

c) the progesterone receptor which is expressed in basal epidermal keratinocytes only ${ }^{38}$.

While the glucocorticoid receptor is down-regulated by its ligands in dermal fibroblasts ${ }^{39}$, AR is stabilized by ligand binding und up-regulated in fibro- blasts and sebocytes ${ }^{40,41}$. Steroid receptors under basal conditions exist as cytoplasmic, polymeric complexes that include the heat shock proteins hsp 90, hsp 70 and hsp 56. Association of the steroid ligand with the receptor results in dissociation of the heat shock proteins. This in turn exposes a nuclear translocation signal previously buried in the receptor structure and initiates transport of the receptor to the nucleus.

The second group, the thyroid receptor family, includes

a) the thyroid hormone receptors (isotypes a1 and b1) which are present in epidermal keratinocytes and dermal fibroblasts ${ }^{42,43}$;

b) the estrogen receptors with the $\beta$-isotype being strongly expressed in the skin detected in epidermal and outer root sheath keratinocytes, melanocytes, dermal fibroblasts, dermal papilla cells, sebocytes, endothelial cells and adipocytes ${ }^{37,44-47,}$ and the $\alpha$-isotype found in sebocytes and dermal fibroblasts in vitro ${ }^{44,47}$.

c) the retinoic acid receptors ( $R A R$; isotypes $\alpha$ and $\gamma$ ) and retinoid $X$ receptors $(R X R$; isotypes $\alpha, \beta, \gamma)$ which are expressed in epidermal keratinocytes of the stratum granulosum, follicular keratinocytes, sebocytes and endothelial cells, while only the RXRa isotype is present in melanocytes, fibroblasts and inflammatory cells ${ }^{48-52}$;

d) the vitamin $D$ receptor $(V D R)$ which is present in keratinocytes of all epidermal layers except those of the stratum corneum, epithelial cells of the epidermal appendages, melanocytes, Langerhans cells, CD11b + macrophages and CD3 + T-lymphocytes $^{53,54}$; and

e) the peroxisome proliferator-related receptors (PPAR) which are expressed in epidermal and follicular keratinocytes, sebocytes, sweat gland cells, endothelial cells and adipocytes (isotype $\gamma$ ), whereas isotypes $\alpha$ and $\delta$ are also expressed in keratinocytes and sebocytes ${ }^{55,56}$. PPAR $\delta$ is the predominant PPAR subtype in human keratinocytes and is highly expressed in basal cells and suprabasal cells.

The members of the thyroid receptor family share a high degree of homology to the proto-oncogene $c$ erbA and high affinity for a common DNA recognition site. With the exception of the estrogen receptor, they do not associate with the heat shock proteins and 
are constitutively bound to chromatin in the nucleus. The estrogen receptor, though demonstrating an association with heat shock proteins, is largely confined to the nuclear compartment ${ }^{47}$. The estrogen receptor binds to its regulatory element as a homodimer, while the other receptors of this family prefer to bind as heterodimers together with a RXR molecule. The latter amplifies both the DNA binding and the functional activity of the receptor.

\section{Biological Activity of Hormones in Human Skin}

PTHrP: The PTHrP inhibits proliferation of dermal fibroblasts in a dose dependent manner, whereas a dose-dependent stimulation of cAMP, released by fibroblasts, can be concomitantly observed ${ }^{57}$. In contrast, PTHrP has no effect on collagen synthesis, whereas it increases metalloproteinase 2 activity. Modulation of the PTH / PTHrP receptor on dermal fibroblasts increases the membrane-associated protein kinase $\mathrm{C}$ activity modulating proliferation of epidermal keratinocytes in a paracrine manner ${ }^{58}$.

CRH: CRH has recently been shown to stimulate sebaceous lipogenesis ${ }^{13}$. On the other hand, CRH inhibits proliferation of keratinocytes and enhances immunoactivity by up-regulating the interferon-gamma-stimulated expression of the hCAM and ICAM-1 adhesion molecules and of the HLA-DR antigen ${ }^{59}$. All these effects are concentration-dependent with maximal activity at $\mathrm{CRH} 10^{-7} \mathrm{M}$.

POMC peptides: There is increasing evidence that the cutaneous nervous system modulates physiological and pathophysiological effects including cell growth and differentiation, immunity and inflammation as well as tissue repair. Both cutaneous nervous fibers and inflammatory cells are able to release neuromediators and thereby activate specific receptors on target cells in the skin. POMC peptides are likely to play a major role in the regulation of the skin pigmentary system $^{4,60}$ and of cutaneous inflammation ${ }^{14,28}$. ACTH and $\alpha-\mathrm{MSH}$ bind to $\mathrm{MC} 1$ of melanocytes and exhibit the most significant melanogenic activity via cAMPdependent pathways and tyrosinase activation, which is enhanced by ultraviolet light ${ }^{12}$. Melanogenesis is a highly regulated process modified by postranslational, translational or transcriptional mechanisms. In addition, dendrite formation and stimulation of melanocyte proliferation by POMC peptides have been reported. $\alpha$-MSH can also stimulate attachment of melanocytes to laminin and fibronectin and inhibit TNF- $\alpha$-stimulated expression of ICAM-1.

In keratinocytes, $\alpha$-MSH stimulates cell proliferation, down-regulates expression of hsp $70^{61}$ and modulates cytokine production with up-regulation of IL-10 and inhibition of the IL-1-induced production and secretion of IL- $8^{14,28}$. The latter effect was also detected in fibroblasts, where it may be mediated by NF-kB and $\mathrm{AP}-1^{62}$. $\alpha-\mathrm{MSH}$ also stimulates synthesis and activity of collagenase/matrix metalloproteinase- 1 in dermal fibroblasts ${ }^{63}$. TNF- $\alpha$ addition resulted in increased $\beta$-endorphin and ACTH levels ${ }^{12}$. In contrast, tumor growth factor- $\beta$ (TGF- $\beta$ )-stimulated fibroblasts showed no alteration in $\beta$-endorphin and $\alpha$-MSH levels, whereas ACTH release was significantly enhanced.

On the other hand, it is likely that overproduction of ACTH may prolong the anagen phase of the hair cycle $^{12}$. In sebocytes, $\alpha$-MSH was shown to stimulate proliferation through its binding to $\mathrm{MC1}$ and lipid synthesis through binding to MC $5^{15,17} \cdot \alpha$-MSH may play a crucial role in endothelial cell function by decreasing the adherence and transmigration of inflammatory cells, a prerequisite for immune and inflammatory reactions ${ }^{12}$. The POMC peptides have strong immunomodulatory potential resulting in an overall immunosuppressive effect with $\alpha$-MSH presenting the widest spectrum of activities ${ }^{14}$, such as suppression of the contact hypersensitivity reaction to nickel by systemic or topical application ${ }^{12}$. $\alpha$-MSH in vitro was found to down-regulate costimulatory molecule expression on dendritic cells and in vivo via the generation of suppressor T-lymphocytes to induce hapten specific tolerance $^{28}$. Both $\alpha$-MSH and $\beta$-endorphin induced histamine release from human foreskin mast cells in vitro $^{64}$.

$\gamma$-MSH also seems to exercise some control over the cutaneous inflammatory process by similar mechanisms to those of $\alpha-\mathrm{MSH}$, namely down-regulating the production of proinflammatory cytokines, while the production of the anti-inflammatory cytokine IL-10 is stimulated ${ }^{65}$.

In addition to its effect on mast cells, $\beta$-endorphin was shown to stimulate cytokeratin 16 expression and down-regulate $\mu$-opiate receptor expression in human epidermis $^{66}$. On the other hand, $\beta$-endorphin has po- 
tent melanogenic, mitogenic and dendritogenic effects in cultured epidermal melanocytes ${ }^{18}$. In sebocytes, $\beta$ endorphin inhibits the EGF-induced proliferation and stimulate lipogenesis ${ }^{19}$.

Melatonin: Melatonin inhibits both apoptosis of keratinocytes incubated in serum-free media and proliferation of keratinocytes cultured in medium supplemented with serum. It increases the numbers of viable fibroblasts incubated in a serum free medium ${ }^{20}$.

VIP: VIP was found to stimulate proliferation of keratinocytes in the presence of lethally treated $3 \mathrm{~T} 3$ fibroblast feeder cells and EGF, whereas substance P and CGRP were ineffective ${ }^{67}$. VIP stimulated adenylate cyclase activity in membranes obtained from cultured keratinocytes, indicating an involvement of cAMP as second messenger in this reaction. VIP and several inflammatory cytokines (Th-1 and 2) from mast cells and nerve endings are capable of inducing stem cell factor production from epidermal keratinocytes, a mechanism that could be involved in atopic dermatitis $^{68}$.

CGRP and PAR-2 agonists: CGRP appears to lead to a reduction of contact hypersensitivity by inducing mast cells to degranulate and thus release TNF- $\alpha$ and, most likely, IL-10 ${ }^{69}$. CGRP, like $\alpha-\mathrm{MSH}$, down-regulates costimulatory molecule expression on dendritic cells in vitro and via the generation of suppressor Tlymphocytes to induce hapten specific tolerance in vivo $^{28}$. PAR-2 agonists were found to induce the release of CGRP mediating vasodilation, plasma extravasation as well as the expression of adhesion molecules on vascular endothelial cells and thus elicit neurogenic inflammation. New evidence suggests that the release of neuropeptides, including CGRP, from cutaneous sensory c-fibers after UV radiation is induced by keratinocyte-derived nerve growth factor ${ }^{69}$.

Serotonin: The relationship between function and serotonin receptor type is complex. Detection of 5HT1A, 5HT1B, 5HT2B and 5HT7 receptors on melanocytes and dermal fibroblasts is consistent with a putative function for serotonin as growth factor ${ }^{70}$. Serotonin stimulates proliferation of melanocytes in a medium deprived of growth factors, while it inhibits cell growth in the presence of growth factors ${ }^{20}$.

Substance P: Substance P is released from cutaneous nerve fibers or mast cells in the extracellular space or at the cell surface to induce inflammatory or immune responses. SP promotes both the proliferation and the differentiation of sebaceous glands ${ }^{71}$. Mast cell-derived IL- 6 and TNF- $\alpha$, followed by SP-stimulated degranulation, have the potential to induce nerve growth factor expression by sebaceous cells, which results in the promotion of innervation and in the expression of E-selectin, respectively. Recently, undifferentiated germinative sebocytes were shown to produce high amounts of neutral endopeptidase in order to inactivate substance $\mathrm{P}$ in vitro and in acne-involved sebaceous glands in vivo ${ }^{72}$.

GH and IGF-I: The effects of the GH/IGF-I axis result in a homeostatic regulation of cell proliferation and differentiation. GH activity is mainly mediated by the IGFs but GH also has direct effects on human skin cells ${ }^{5}$. GH enhances androgen effects on hair growth and is likely to be involved in sebaceous gland development. It stimulates sebocyte differentiation and also augments the effect of $5 \alpha$-DHT on sebaceous lipid synthesis ${ }^{73}$. On the other hand, GH does not affect keratinocyte or sebocyte proliferation though it enhances the proliferation of dermal fibroblasts in vit$\mathrm{ro}^{29,73}$. IGF-I and insulin have been shown to significantly stimulate sebocyte proliferation but also influence sebocyte differentiation, especially in combination with $\mathrm{GH}$, in vitro ${ }^{73,74}$. Insulin may act as an IGF-I surrogate as it exhibits marked homology to the IGFs and binds the IGF-I receptor at high concentrations. IGF-I was also shown to promote clonal proliferation of cultured keratinocytes ${ }^{29}$ and to up-regulate hyaluroran synthesis in dermal fibroblasts, exhibiting a similar effect to basal fibroblast growth factors ${ }^{75}$. GH and IGF-I induce increases in skin IGF-binding protein-3 mRNA abundance ${ }^{76}$ with a magnitude dependent on the presence of $\mathrm{Ca}^{2+}$. IGF-I at physiological levels is essential for hair follicle growth by preventing them from entering the catagen phase ${ }^{77}$. IGF molecules circulate mostly bound to IGF-binding proteins. The GH / IGF-I axis shows an age-related decreased hormone production concomitant with symptoms similar to those of GH-deficient adults ${ }^{78}$. Finally, GH is able to switch the predominant CRH receptor-1 mRNA expression to a sole $\mathrm{CRH}$ receptor- 2 mRNA expression in human sebocytes ${ }^{13}$, indicating a possible interaction of the GH/IGF-I axis with the hypothalamic-pituitaryadrenal axis in human skin. Skin is a target organ for $\mathrm{GH}$ in children; growth hormone increases dermal thickness and reduces skin stiffness in growth hormone-deficient children ${ }^{79}$. The IGF-I / IGF-I recep- 
tor loop was found to be critically involved in maintenance of human skin organ cultures ex vivo ${ }^{30}$; IGF-I locally produced by dermal fibroblasts interacted in a paracrine manner with its receptor, predominantly expressed in basal keratinocytes, to maintain tissue homeostasis.

Thyroid hormones: Hypothyroidism causes disturbances of skin quality and hair character and growth with an increased telogen rate and diffuse alopecia ${ }^{5,6}$. Replacement reestablishes the normal anagen/telogen ratio. L-Triiodothyronine was shown to stimulate proliferation of outer root sheath keratinocytes and dermal papilla cells ${ }^{80}$.

Androgens: The biological activity of testosterone on the skin is induced in large part by its conversion to $5 \alpha$-DHT by $5 \alpha$-reductase ${ }^{81,82}$. Testosterone and $5 \alpha-$ DHT, being the tissue active androgens, stimulate $5 \alpha$ reductase mRNA and $5 \alpha$-reductase activity and their effects are mediated through their binding to the AR. They stimulate proliferation of target cells, such as sebocytes and dermal papilla cells ${ }^{83-86}$. In addition, there is evidence that the effect of androgens on human sebocyte proliferation depends on the area of skin from which the sebaceous glands are obtained; facial sebocytes are mostly affected ${ }^{83,87}$. Androgens as single compounds seem to be unable to modify sebocyte differentiation ${ }^{56}$, which is stimulated by co-incubation with PPAR $\gamma$ ligands $^{88}$. Dermal papilla cells mediate the growth-stimulating signals of androgens by releasing growth factors that act in a paracrine fashion on the other cells of the follicle ${ }^{5,86}$. Excessive amounts of tissue active androgens were shown to induce apoptosis of dermal papilla cells through the bcl-2 pathway $^{89}$. In aged skin, lower serum levels of testosterone and gradual decline in DHEA and DHEA sulfate are detected, at least in males ${ }^{78}$. Unexpectedly, testosterone has been reported to perturb epidermal permeability barrier homeostasis. ${ }^{90}$

Estrogens: For many years it has been recognized that estrogens are important in the maintenance of human skin ${ }^{91}$. They improve collagen content and quality, increase skin thickness and enhance vascularization, features highlighted by the changes that occur in the skin of postmenopausal women ${ }^{92}$. They have been shown to increase mitotic activity in the epidermis of women $^{93}$. Estrogens prolong the growth period of scalp hair by increasing cell proliferation rates and postponing the anagen-telogen transition ${ }^{86}$. In parallel,
$17 \alpha$-estradiol, as a therapeutic compound, induces aromatase activity in intact human anagen hair follicles ex vivo.Under the influence of $17 \alpha$-estradiol, an increased conversion of testosterone to $17 \beta$-estradiol and androstendione to estrone takes place, which might explain the beneficial effects of estrogen treatment of androgenic alopecia ${ }^{94} .17 \beta$-Estradiol exerts anti-inflammatory activity by inhibiting the chemokine RANTES and an interferon- $\gamma$-induced $10 \mathrm{kDa}$ protein produced in human keratinocytes ${ }^{95,96}$. On the other hand, estrogens directly suppress an enhanced sebaceous gland function ${ }^{12,97}$. Both testosterone and estradiol are able to regulate CRH receptor mRNA levels in sebocytes, through an opposite way ${ }^{13}$. Estradiol has also been shown to increase proliferation of melanocytes but decrease both the melanin content and the tyrosinase activity ${ }^{98}$. Inhibition of $5 \alpha$-reductase and of AR activity resulted in a great stimulation of vascular endothelial growth factor (VEGF) and aromatase expression in dermal papilla cells. Strong stimulation of VEGF protein and gene expression was also observed in the presence of $17 \beta$-estradiol ${ }^{37}$. Rapid potentiation of endothelium-dependent vasodilation by $17 \beta$-estradiol in postmenopausal women is mediated via cyclooxygenase $2^{99}$. There is current evidence that although skin cells express estrogen receptors making them directly susceptible to estrogens, a cross-talk between estrogen and IGF-I signaling pathways obviously takes place. IGF-I plays a major role in regulating lipid synthesis in sebocytes and proliferation in fibroblasts and may, therefore, mediate the estrogen activity in normal and aged skin cells ${ }^{100}$. On the other hand, phytoestrogens, such as genistein, probably regulate sebocyte differentiation through up-regulation of PPAR $\gamma$ expression ${ }^{56}$.

Glucocorticoids: Glucocorticoids induce hair growth $^{101}$, stimulate sebocyte proliferation ${ }^{74}$ and induce skin atrophy, probably due to an effect on dermal fibroblasts ${ }^{102}$. The aggravation of sebaceous gland diseases by glucocorticoids may be due to their stimulatory effects on proliferation and differentiation in the presence of other growth factors ${ }^{12}$. Glucocorticoids can regulate keratinocyte differentiation by repressing the expression of the basal cell specific keratins $\mathrm{K} 5$ and K14 and disease-associated keratins K6, K16, and K17, an effect induced directly through interactions of keratin response elements with glucocorticoids, and indirectly by blocking the AP-1 induction of keratin gene expression $^{103}$. 
Retinoids: Retinoic acids exhibit earlier and stronger biological effects on the keratinocytes than retinol, probably due to their early high cellular accumulation and their less rapid metabolism ${ }^{104,105}$. These findings substantiate the assumption that the intensity of retinoid signaling is dependent, in part, on the quantity of cellular retinoic acid. This assumption is supported by the tight autoregulatory mechanism in human keratinocytes offering protection against excessive accumulation of cellular retinoic acid ${ }^{49}$. all-trans Retinoic acid binds to and induces cellular retinoic acidbinding protein II as well as binding to and activating nuclear RARs ${ }^{106}$. Most actions of all-trans retinoic acid are now recognized to be mediated through activation of RARs, whereas in epithelial skin cells, RAR modulate cell proliferation and RXR rather than influence cell differentiation ${ }^{51}$. Retinoids regulate proliferation and differentiation of skin epithelial cells towards a homeostatic status ${ }^{105}$ notably inhibiting proliferation and lipogenesis in human sebocytes but enhancing these processes under vitamin A deficient conditions $^{107,108}$.

Vitamin D: $1 \alpha, 25(\mathrm{OH})_{2} \mathrm{D}_{3}$ (calcitriol), the hormonal form of vitamin $\mathrm{D}$, like retinoids, rapidly up-regulates the major vitamin $\mathrm{D}_{3}$ (cholecalciferol) metabolizing enzyme 25-hydroxylase at the mRNA level, which is an established indicator for calcitriol presence ${ }^{109}$. It enhances the growth-promoting activity of autocrine EGF receptor ligands in keratinocytes ${ }^{110}$ and can also rapidly increase the activity of $17 \beta$-hydroxysteroid dehydrogenase (isotype 2), which leads predominantly to conversion of estradiol to estrone ${ }^{111}$. This estradiol inactivation is enhanced with increasing calcitriol levels, which exhibit an antiproliferative effect on keratinocytes. This effect, which is mediated through TGF$\beta$ activation as well as IL- $1 \alpha$, IL- 6 and IL- 8 suppression, may provide a rationale for the beneficial effects of calcitriol and synthetic analog in the treatment of hyperproliferative skin disorders, whereas stimulatory effects through the EGF-related family members and platelet-derived growth factor may be operative in their beneficial effects in skin atrophy and wound healing ${ }^{112}$. The antiproliferative and antiinflammatory effects of calcitriol in skin are also mediated, at least in part, by a complex TGF- $\beta$ regulation in dermal fibroblasts ${ }^{113}$. Calcitriol also elicits the complete differentiative program in vitro, with expression of various genes/proteins, especially of protein kinase $\mathrm{C}$ and phospholipase $\mathrm{D}$, characteristic of both early and late differentiation of keratinocytes ${ }^{114}$. In addition to its effects on keratinocyte proliferation and differentiation, calcitriol has been shown to protect keratinocytes from ultraviolet light- and chemotherapy-induced damage by inhibition of stress-activated protein kinases activation ${ }^{115}$. On the other hand, in vitro and in vivo experiments have shown that VDR ligands induce dendritic cells to acquire tolerogenic properties that favor the induction of regulatory rather than effector $\mathrm{T}$ cells ${ }^{116}$.

Leptin: Leptin is a keratinocyte acting in vitro, and during skin repair in vivo, through a cytoplasmic activation of the signal transcription factor STAT- $3^{117}$. In addition, leptin exhibits a proangiogenic activity probably through a bcl-2 dependent anti-apoptotic action on microvascular endothelial cells ${ }^{118}$.

PPAR ligands: PPARs are pleiotropic regulators of growth and differentiation of many cell types, including skin cells. PPAR $\alpha$ seems to contribute to skin barrier function and to regulation of inflammation, PPAR $\gamma$ is necessary for keratinocyte and sebocyte differentiation, and PPAR $\delta$ can ameliorate inflammatory responses in the $\operatorname{skin}^{55}$. PPAR $\delta$ is the predominant subtype in human keratinocytes and is highly expressed in basal and suprabasal cells ${ }^{119,120}$. Induction of PPAR $\alpha$ and PPAR $\gamma$ expression is linked to differentiation and, accordingly, their expression is in essence confined to suprabasal cells ${ }^{120}$. PPAR $\delta$ and PPAR $\gamma$ inhibition resulted in a dramatic decrease in proliferation and a robust up-regulation of the expression of involucrin and transglutaminase ${ }^{120,121}$. PPARs are expressed in the human sebaceous gland ${ }^{56,122,123}$. Linoleic acid, a natural PPAR ligand, induces accumulation of neutral lipids in undifferentiated human sebocytes and reduces spontaneous IL-8 secretion ${ }^{124}$. Estradiol metabolizes prostaglandin $\Delta 2$ to $\Delta 12$-prostaglandin J2, a natural ligand for PPAR $\gamma^{125}$, whereas the expression of PPAR $\gamma$ is up-regulated by the phytoestrogen genistein ${ }^{56}$.

Eicosanoids: Proinflammatory cytokines, such as IL-1 $\beta$ and TNF- $\alpha$, induce cytosolic phospholipase $\mathrm{A}_{2}$ expression in keratinocytes and are able to increase the release of arachidonic acid and stimulate eicosanoid synthesis ${ }^{126}$. IL1 $\alpha$ expression has been detected in follicular keratinocytes and sebocytes in vivo and in vitro ${ }^{74,126-128}$. Enhanced keratinocyte prostaglandin synthesis after UV light injury is also due to increased phospholipase activity ${ }^{129}$. The major arachi- 
donic acid metabolites in skin cells are prostaglandin $\mathrm{E}_{2}$ and leukotriene $\mathrm{B}_{4}\left(\mathrm{LTB}_{4}\right)^{130}$, while TNF- $\alpha$ stimulates hydroxyeicosatetranoic acid (HETE) production. Interestingly, $\mathrm{LTB}_{4}$ is a natural ligand for PPAR $\alpha^{131-133}$, soluble 15-HETE, which is a natural ligand for PPAR $\gamma^{134}$ and is synthesized in human sebaceous glands ${ }^{135}$, and PPARs can regulate lipid and lipoprotein metabolism, cell proliferation, differentiation and apoptosis of various cell types including sebocytes ${ }^{88,133}$. The axis arachidonic acid/LTB $/$ PPAR $\alpha /$ lipid synthesis and inflammation in human skin (Figure 2) was confirmed by a recent clinical study demonstrating that treatment of acne patients with zileuton, a selective 5-lipoxygenase inhibitor administered systemically, led to a $70 \%$ reduction in inflammatory acne lesions at 3 months and an approximately $65 \%$ reduction in total sebum lipids as well as a substantial decrease in proinflammatory lipids ${ }^{136}$.

\section{THE HUMAN SKIN AS ENDOCRINE GLAND}

\section{Hormone Synthesis in Human Skin}

All types of small molecules can practically represent precursors of skin hormones which may be proteins, in-

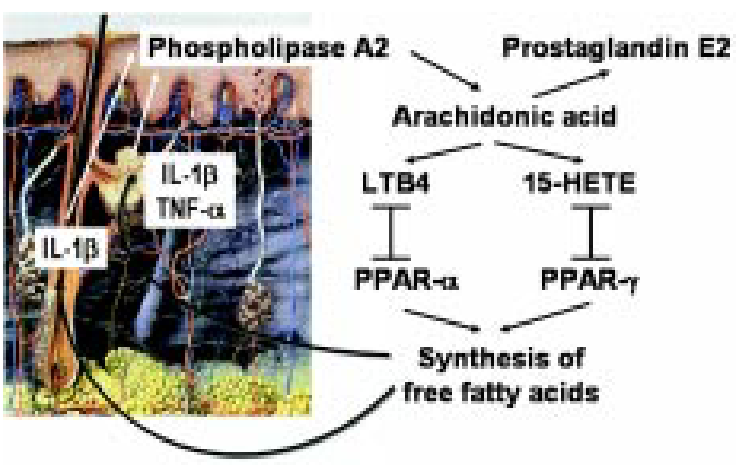

Figure 2. The cascade of eicosanoid synthesis and their PPAR-binding in human skin. IL-1 $\beta$, interleukin-1 $\beta$; TNF- $\alpha$, tumor necrosis factor- $\alpha$; LTB4, leucotriene B4; 15-HETE, 15-hydroxyeicosatetranoic acid; PPAR- $\alpha$, peroxisome proliferator-activated receptor- $\alpha$; PPAR- $\gamma$, peroxisome proliferator-activated receptor- $\gamma$.

cluding glycoproteins, smaller peptides or peptide derivatives, amino acid analogs or lipids (Figure 3 ).

PTHrP: Keratinocytes produce abundant PTHrP which is down-regulated by calcitriol, suggesting a physiological role ${ }^{137}$. In addition, PTHrP is widely expressed in melanocytic cells; however, these cells do

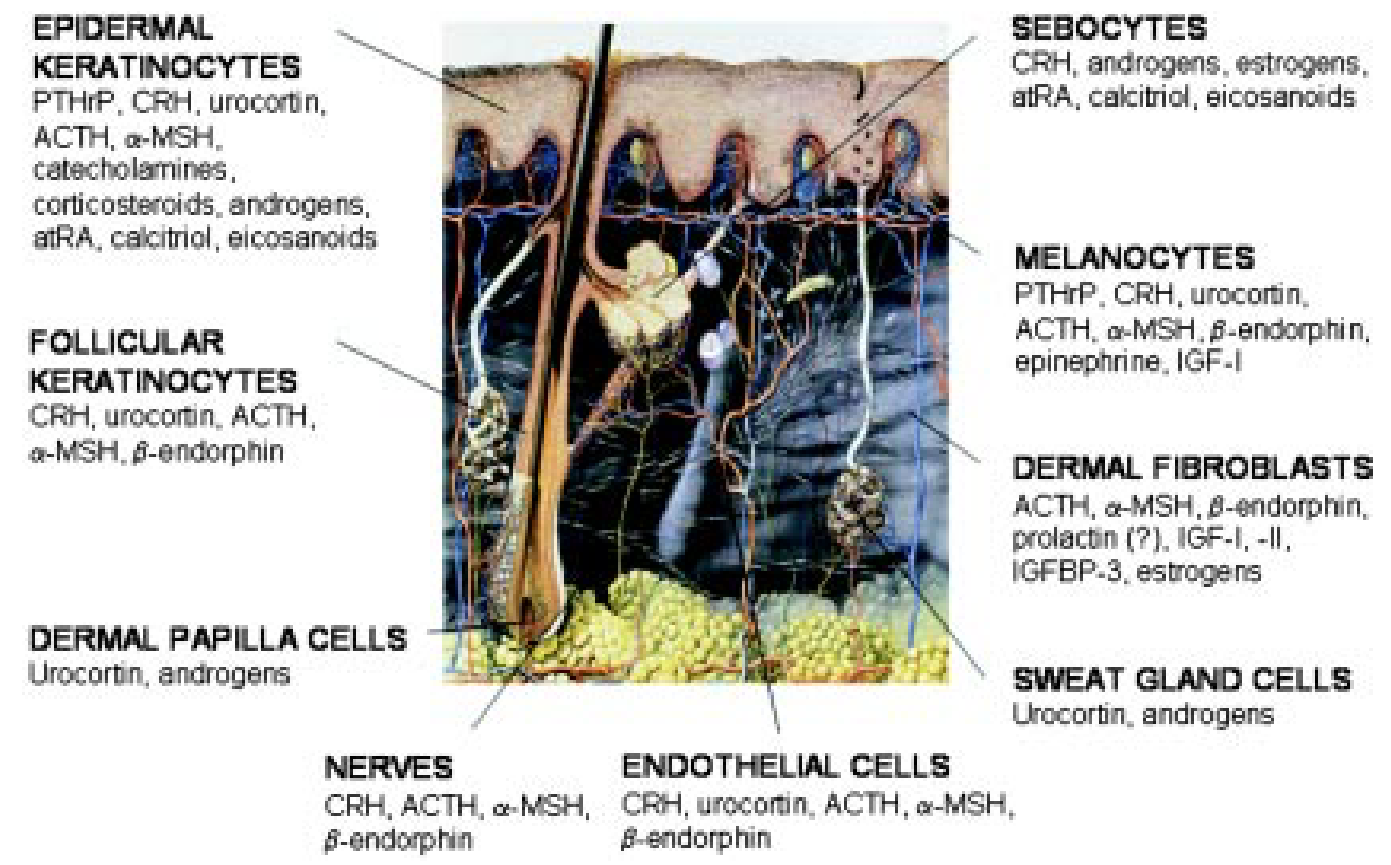

Figure 3. Synthesis of hormones in human skin. PTHrP, parathyroid hormone-related peptide; $\mathrm{CRH}$, corticotropin-releasing hormone; ACTH, adrenocorticotropic hormone; $\alpha$-MSH, $\alpha$-melanocyte-stimulating hormone; atRA, all-trans retinoic acid; IGF-I, insulin-like growth factor-I; IGF-II, insulin-like growth factor-II; IGFBP3, insulin-like growth factor-binding protein-3. 
not secrete $\mathrm{PTHrP}^{138}$.

CRH and urocortin: CRH, modified amino acid as well as CRH binding protein are expressed in human sebocytes at the mRNA and protein levels ${ }^{13}$ and have also been detected in epidermal and follicular keratinocytes, melanocytes, endothelial cells and dermal nerves but not in fibroblasts ${ }^{12}$.

The gene of the CRH-related urocortin, a ligand of CRH-2 receptor, and accumulation of the corresponding peptide have been detected in human skin cells ${ }^{139}$. Urocortin antigen has been localized to epidermal and follicular keratinocytes and sweat glands, epidermal melanocytes, blood vessels walls, dermal smooth muscle, mononuclear inflammatory cells and dermal fibroblasts.

POMC peptides: POMC mRNA is expressed in melanocytes ${ }^{18}$. POMC cleavage products, such as ACTH, MSH isotypes and $\beta$-endorphin, are produced in several skin cell types in vivo and in vitro ${ }^{12,14,140}$. $\mathrm{ACTH}$ and $\alpha$-MSH are mainly expressed in epidermal keratinocytes, melanocytes, the outer root sheath of the anagen hair follicle, dermal fibroblasts and microvascular endothelial cells. $\beta$-Endorphin is mainly produced by the outer root sheath of the anagen hair follicle and dermal fibroblasts.

Prolactin: Recent data on prolactin synthesis in human skin are controversial. While dermal fibroblasts in vitro were shown to synthesize prolactin in one study ${ }^{141}$, no prolactin mRNA was detected in human skin in another study ${ }^{142}$.

Catecholamines: Norepinephrine and epinephrine, which are modified amino acids and natural activators of the cAMP pathway, are produced in human keratinocytes but not in melanocytes ${ }^{143}$.

IGF-I: Although there is no evidence that GH or GH-like peptides are produced in the skin, its downstream peptide, IGF-I, is synthesized in the skin, mainly by dermal fibroblasts and melanocytes and also possibly by keratinocytes of the stratum granulosum ${ }^{29,144}$. Dermal fibroblasts are also a source of IGF-II and IGF-binding protein- $3^{145,146}$.

Steroid hormones: The skin, especially the sebaceous glands, is capable of synthesizing cholesterol from two-carbon fragments such as acetate ${ }^{147,148}$ - which is utilized in cell membranes for the formation of the epidermal barrier, in sebum, and as substrate for ste- roid hormone synthesis in the skin, and especially in the sebaceous gland ${ }^{149}$. The local formation of sex steroids provides autonomous control to human skin which is thus able to adjust the formation and metabolism of sex steroids according to local needs ${ }^{3,7,149}$. The situation of a high secretion rate of adrenal precursor sex steroids in men and women is completely different from the animal models used in the laboratory (except monkeys), where the secretion of sex steroids takes place exclusively in the gonads. In these lower animal species, no significant amounts of androgens or estrogens are synthesized outside the testes or ovaries and no sex steroid is detected after castration. Sex steroids in human skin are activated intracellularly and exert their action within the cells without release in the extracellular space and in the general circulation (intracrine function) ${ }^{7}$. The rate of formation of each sex steroid thus depends upon the level of expression of each of the specific androgen- and estrogen-synthesizing enzymes in each cell type. Sebaceous glands and sweat glands account for the vast majority of androgen metabolism in skin $^{3,5}$.

Skin is also a source of corticosteroids ${ }^{102}$.

Retinoids: In humans, vitamin A (retinol) and natural retinoids are derived from carotenoids in the diet that are modified by the body; in the skin, excess retinol is mainly esterified ${ }^{106,150}$. Human keratinocytes in vitro are able to produce low amounts of the intracellularly active metabolite all-trans retinoic acid ${ }^{104,105,151}$.

Vitamin D: The skin is the unique site of cholecalciferol synthesis ${ }^{152,153}$ which, like steroid hormones, derives from cholesterol. Epidermal keratinocytes contain both the mechanism needed to produce calcitriol and $\mathrm{VDR}^{116}$.

Eicosanoids: Eicosanoids, such as prostaglandins, prostacyclins and leukotrienes, are fatty acid derivatives. Eicosanoid synthesis can also be induced in human keratinocytes and sebocytes by several proinflammatory signals ${ }^{129,130,154}$.

\section{Activation and Inactivation of Hormones in Human Skin}

In addition to its capacity to produce hormones, the human skin is able to metabolize hormones in order to activate or inactivate them. These metabolic steps are undertaken in most cases by different skin cell populations in a coordinated way, indicating the 
endocrine autonomy of the skin. Characteristic examples of this kind of endocrine skin function are the metabolic pathways of the CRH / POMC axis, sex steroids, vitamin $\mathrm{D}$ and retinoids.

The CRH/POMC axis: The skin is strategically located as a barrier between the external and internal environments being permanently exposed to noxious stressors. To effectively deal with such damaging signals, the skin exhibits a highly organized CRH / POMC system which is analogous to the hypothalamic-pituitary-adrenal axis and is a major stress response system $^{12}$. Activation of this pathway by stress-sensoring cutaneous signals, mainly proinflammatory cytokines, proceeds through the production and release of $\mathrm{CRH}$ from keratinocytes, melanocytes, endothelial cells and dermal nerves which stimulate skin cell CRH receptors in a paracrine and autocrine manner. CRH synthesis in melanocytes is up-regulated by ultraviolet radiation $\mathrm{B}$ and down-regulated by dexamethasone ${ }^{12}$. Interestingly, $\mathrm{CRH}$ receptors in human sebocytes can be regulated by several other downstream hormones, mainly by testosterone, estrogens and $\mathrm{GH}^{13}$. $\mathrm{CRH}$ enhances the production and secretion of the POMC peptides $\alpha$-MSH, ACTH, and $\beta$-endorphin, especially in keratinocytes, melanocytes, endothelial cells and cutaneous nerves ${ }^{14,140}$ by a complex multistep process that requires POMC processing by prohormone convertases $^{12}$. These enzymes are expressed in keratinocytes, melanocytes and endothelial cells. Production of $\alpha-\mathrm{MSH}$ and ACTH can be significantly upregulated by ultraviolet light and IL-1 and down-regulated by TGF- $\beta$ and dexamethasone. ACTH activates the steroidogenic acute regulatory protein and thus the MC receptors inducing, thereby, the production and secretion of cortisol ${ }^{155}$, a powerful natural antiinflammatory factor that counteracts the effect of stress signals and buffers tissue damage.

Steroidogenesis: Human sebocytes and keratinocytes express the steroidogenic acute regulatory protein which is essential for cholesterol translocation from the outer to the inner mitochondrial membrane and thus the initiation of steroidogenesis ${ }^{149}$ (Figure 4). They also express P450 side chain cleavage enzyme which catalyses the conversion of cholesterol into pregnenolone, cytochrome P450 17-hydroxylase that leads to precursors of cortisol and DHEA, and steroidogenic factor-1 which maintains these reactions. DHEA can be further converted into androstenedione and the tissue potent androgen testosterone by sebocytes and dermal papilla cells since they express $3 \beta$-hydroxysteroid dehydrogenase- $\Delta^{5-4}$ isomerase ${ }^{3,156,157}$. Further activation of testosterone by its conversion into $5 \alpha$ DHT is catalyzed by $5 \alpha$-reductase type 1 which is expressed in almost all skin cells but especially in sebocytes $^{81}$, while fibroblasts and dermal papilla cells also express $5 \alpha$-reductase type $2^{37}$. Sebocytes are also able to regulate the balance of testosterone and androstenedione bidirectionally by expressing the $17 \beta$-hydroxysteroid dehydrogenase isotypes 2 and $3^{3}$. Androgen conversion to estrogens in the skin takes place in dermal fibroblasts which express the responsible enzyme cytochrome P450 19 (aromatase), and androgen inactivation to androsterone or $3 \alpha$-androstanediol in epidermal keratinocytes which strongly express the responsible enzyme $3 \alpha$-hydroxysteroid dehydrogena$\mathrm{se}^{3,158}$. In contrast to this skin-related pathway, conversion of the adrenal DHEA sulfate - which reaches the skin through the circulation - to DHEA occurs with the assistance of dermal papilla cells and monocytes which exhibit steroid sulfatase activity ${ }^{156,157,159}$. Therefore, the skin is a steroidogenic tissue and different skin cell types exert distinct duties in the synthesis of tissue active androgens and their inactivation leading to androgen and estrogen homeostasis. Adrenal androgens may only be activated in the skin in pathologic conditions which require the presence of inflammatory cells in the skin.

In addition, evaluation of skin layer-specific prednicarbate biotransformation has shown that epidermal keratinocytes can hydrolyze the double ester prednicarbate at position 21 to the monoester prednisolone 17-ethylcarbonate which nonenzymatically transforms to prednisolone 21-ethylcarbonate. This metabolite is enzymatically cleaved to prednisolone, the main biotransformation corticosteroid product. Fibroblasts show a distinctively lower enzyme activity ${ }^{102}$. Prednicarbate, prednisolone 17-ethylcarbonate and prednisolone 21-ethylcarbonate are hydrolyzed to a minor extent only. Therefore, epidermal keratinocytes are likely to be responsible for the conversion of potent corticosteroids to less potent ones in human skin, while dermal fibroblasts are barely able to metabolize the steroids.

The retinoid pathway: Epidermal keratinocytes in vivo regulate the levels of the intracellularly active alltrans retinoic acid by induction of retinoic acid 4-hy- 


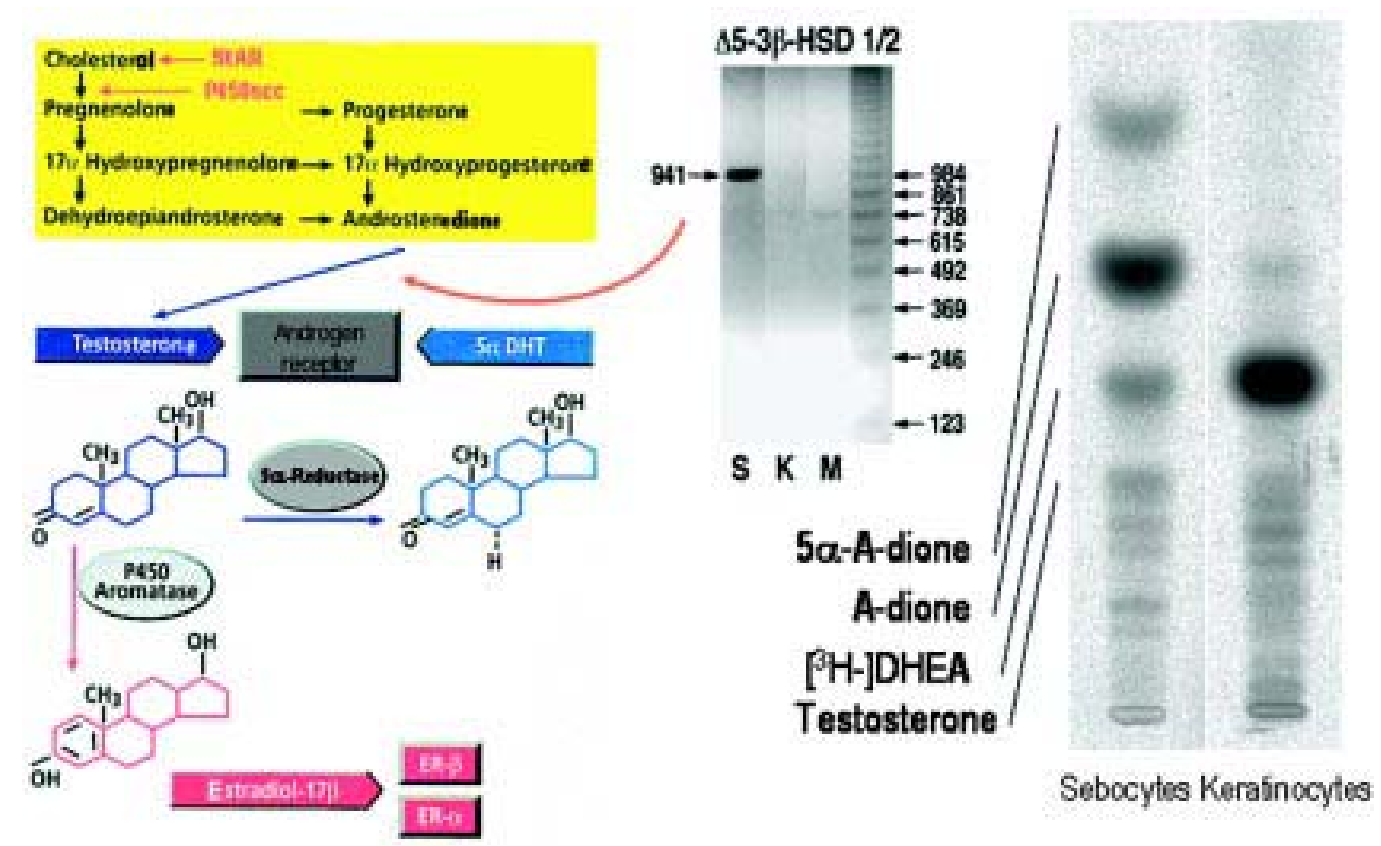

Figure 4. Steroidogenesis in human skin. Left panel: The complete pathway of sex hormone synthesis from cholesterol. StAR, steroidogenic acute regulatory protein; P450scc, cytochrome P450 side chain cleavage enzyme; $5 \alpha$-DHT, $5 \alpha$-dihydrotestosterone; ER, estrogen receptor. Middle panel: Sebocytes (S), but neither keratinocytes (K) nor melanocytes (M), express $3 \beta$-hydroxysteroid dehydrogenase- $\Delta^{5-4}-$ isomerase

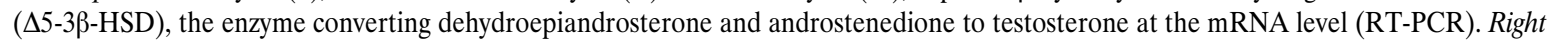
pannel: Sebocytes but not keratinocytes are able to metabolize ${ }^{3} \mathrm{H}$-dehydroepiandrosterone $\left(\left[{ }^{3} \mathrm{H}-\right] \mathrm{DHEA}\right)$ to downstream androgen compounds.

droxylase ${ }^{160}$. atRA inactivation by 4-hydroxylation prevents endogenous and exogenous all-trans retinoic acid accumulation in the epidermis. In contrast to all-trans retinoic acid, retinol, retinaldehyde, 9-cis retinoic acid and 13-cis retinoic acid are not able to regulate their own hydroxylation. In contrast, human keratinocytes in vitro rapidly take up and initially convert retinol to retinyl esters and then with time to low amounts of the intracellularly active metabolite all-trans retinoic $\operatorname{acid}^{104,105,151}$. 3,4-Didehydro-retinol can also be detected $^{105,160}$. However, ester formation, especially of retinyl oleate (18:1) and retinyl palmitate (16:0), remains the main root by which excess retinol is also handled by human keratinocytes in vitro ${ }^{104,105,151,161}$. Retinoid metabolism in human skin is likely to be a cell-specific event since sebocytes exhibit a distinct metabolic pattern compared to epidermal keratinocytes ${ }^{51}$.

The vitamin D pathway: The skin is the unique site of cholecalciferol production and the liver is thought to be the main site of conversion to $25(\mathrm{OH}) \mathrm{D}_{3}$.
The skin is further capable of activating $25(\mathrm{OH}) \mathrm{D}_{3}$ via $1 \alpha$-hydroxylation and the resulting calcitriol plays a role in epidermal homeostasis in normal and diseased skin. Human keratinocytes have been shown to substantially but slowly convert ${ }^{3} \mathrm{H}-\mathrm{D}_{3}$ to ${ }^{3} \mathrm{H}-25(\mathrm{OH})$ $\mathrm{D}_{3}{ }^{109}$. In addition, they were found to slowly but constantly form calcitriol from a large reservoir of cholecalciferol. Interestingly, physiological doses of ultraviolet light $B$ radiation at $300 \mathrm{~nm}$ induce the conversion of 7-dehydrocholesterol via pre-cholecalciferol and cholecalciferol into calcitriol in the pmol range in epidermal keratinocytes ${ }^{153}$. Skin can further degrade cholecalciferol: Cytochrome P450 27 in epidermis completes the set of essential cholecalciferol hydroxylases ${ }^{109}$. Thus, by orchestrating the entire system of production, activation and inactivation, skin is an autonomous source of hormonally active calcitriol.

\section{Release of Skin Hormones in the Circulation}

There is increasing evidence that human skin produces hormones which are released in the circulation 
and are important for functions of the entire human $\operatorname{organism}^{162}$. For example, IGF-binding protein-3 message abundance is greater in the skin than in the liver and circulating IGF-binding protein- 3 concentrations are significantly increased by $\mathrm{GH}$ and $\mathrm{IGF}-\mathrm{I}^{76}$. GH has a direct effect on the regulation of IGF-binding protein-3 synthesis, and the response of skin IGF-binding protein-3 mRNA levels to both GH and IGF-I suggests that dermal fibroblasts could be more important than the liver in the regulation of the circulating reservoir of IGF-binding protein-3 in certain circumstances.

A large proportion of androgens and estrogens in men and women are synthesized locally in the skin from the inactive adrenal precursors DHEA and androstenedione. DHEA and androstenedione are converted to testosterone and further to $5 \alpha$-DHT by the intracellular enzyme $5 \alpha$-reductase in skin, thus making the skin a source of considerable amounts of the circulating testosterone and $5 \alpha$-DHT levels. Circulating testosterone is co-produced in the skin and in other peripheral organs ${ }^{8}$. The best estimate of the intracrine formation of estrogens in peripheral tissues in women is in the order of $75 \%$ before menopause and close to $100 \%$ after menopause, except for a small contribution from ovarian and/or adrenal testosterone and androstenedione ${ }^{7}$. Thus, in postmenopausal women, almost all active sex steroids are made in target tissues by an intracrine mechanism.

\section{REFERENCES}

1. Zouboulis ChC, 2000 Human skin: An independent peripheral endocrine organ. Horm Res 54: 230-242.

2. Ebling FJG 1990 The hormonal control of hair growth In Orfanos CE, Happle R (eds) Hair and Hair Growth, Berlin, Heidelberg, New York: Springer; pp, 267-299.

3. Fritsch M, Orfanos CE, Zouboulis ChC, 2001 Sebocytes are the key regulators of androgen homeostasis in human skin. J Invest Dermatol 116: 793-800.

4. Suzuki I, Cone CD, Im S, Nordlund J, Abdel-Malek ZA, 1996 Binding of melanocortin hormones to the melanocortin receptor MC1R on human melanocytes stimulates proliferation and melanogenesis. Endocrinology 137: 1627-1633.

5. Deplewski D, Rosenfield RL, 2000 Role of hormones in pilosebaceous unit development. Endocrine Rev 21: 363392.

6. Stenn KS, Paus R, 2001 Control of hair follicle cycling. Physiol Rev 81: 449-494.

7. Labrie F, Luu-The V, Labrie C, Pelletier G, El-Alfy M, 2000 Intracrinology and the skin. Horm Res 54: 218-229.
8. Orfanos CE, Adler YD, Zouboulis ChC, 2000 The SAHA syndrome. Horm Res 54: 251-258.

9. Pun KK, Arnaud CD, Nissenson RA, 1988 Parathyroid hormone receptors in human dermal fibroblasts: structural and functional characterization. J Bone Miner Res 3: 453-460.

10. Hanafin NM, Chen TC, Heinrich G, Segre GV, Holick MF, 1995 Cultured human fibroblasts and not cultured human keratinocytes express a $\mathrm{PTH} / \mathrm{PTHrP}$ receptor mRNA. J Invest Dermatol 105: 133-137.

11. Slominski A, Wortsman J, Kohn L, et al, 2002 Expression of hypothalamic-pituitary-thyroid axis related genes in the human skin. J Invest Dermatol 119: 1449-1455.

12. Slominski A, Wortman J, Luger T, Paus R, Solomon S, 2000 Corticotropin releasing hormone and propiomelanocortin involvement in the cutaneous response to stress. Physiol Rev 80: 979-1020.

13. Zouboulis ChC, Seltmann H, Hiroi N, et al, 2002 Corticotropin releasing hormone: an autocrine hormone that promotes lipogenesis in human sebocytes. Proc Natl Acad Sci USA 99: 7148-7153.

14. Böhm M, Luger TA, 2000 The role of melanocortins in skin homeostasis. Horm Res 54: 287-293.

15. Böhm M, Schiller M, Ständer S, et al, 2002 Evidence for expression of melanocortin-1 receptor in human sebocytes in vitro and in situ. J Invest Dermatol 118: 533-539.

16. Thiboutot D, Sivarajah A, Gilliland K, Cong Z, Clawson G, 2000 The melanocortin 5 receptor is expressed in human sebaceous glands and rat preputial cells. J Invest Dermatol 115: 614-619.

17. Zhang L, Anthonavage M, Huang Q, Li WH, Eisinger M, 2003 Proopiomelanocortin peptides and sebogenesis. Ann N Y Acad Sci 994: 154-161.

18. Kauser S, Schallreuter KU, Thody AJ, Gummer C, Tobin DJ, 2003 Regulation of human epidermal melanocyte biology by beta-endorphin. Invest Dermatol 120: 1073-1080.

19. Li Z, Ständer S, Luger TA, Zouboulis ChC, Böhm M, 2003 Expression of opioid receptors in human sebocytes - another link between stress and acne? Exp Dermatol 12: 332 .

20. Slominski A, Pisarchik A, Zbytek B, Tobin DJ, Kauser S, Wortsman J, 2003 Functional activity of serotoninergic and melatoninergic systems expressed in the skin. J Cell Physiol 196: 144-153.

21. Heinz-Erian P, Paul S, Said SI, 1986 Receptors for vasoactive intestinal peptide on isolated human sweat glands. Peptides 7: Suppl 1: 151-154.

22. Lundeberg L, Nordlind K, 1999 Vasoactive intestinal polypeptide in allergic contact dermatitis: an immunohistochemical and radioimmunoassay study. Arch Dermatol Res 291: 201-206.

23. Seiffert K, Zouboulis ChC, Seltmann H, Granstein RD, 2000 Expression of neuropeptide receptors by human sebocytes and stimulatory effect of their agonists on cytokine production. Horm Res 53: 102.

24. Fischer TC, Dinh QT, Peiser C, Loser C, Fischer A, Groneberg DA, 2002 Simultaneous detection of receptor mRNA and ligand protein in human skin tissues. J Cutan 
Pathol 29: 65-71.

25. Torii H, Tamaki K, Granstein RD, 1998 The effect of neuropeptides/hormones on Langerhans cells. J Dermatol Sci 20: 21-28.

26. Talley NJ, 2001 Serotoninergic neuroenteric modulators. Lancet 358: 2061-2068.

27. Hollenberg MD, Compton SJ, 2002 International Union of Pharmacology. XXVIII. Proteinase-activated receptors. Pharmacol Rev 54: 203-217.

28. Luger TA, 2002 Neuromediators - A crucial component of the skin immune system. J Dermatol Sci 30: 87-93.

29. Tavakkol A, Elder JT, Griffiths CE, et al, 1992 Expression of growth hormone receptor, insulin-like growth factor 1 (IGF-1) and IGF-1 receptor mRNA and proteins in human skin. J Invest Dermatol 99: 343-349.

30. Tavakkol A, Varani J, Elder JT, Zouboulis ChC, 1999 Maintenance of human skin in organ culture: Role for insulin-like growth factor-1 receptor and epidermal growth factor receptor. Arch Dermatol Res 291: 643-651.

31. Lobie PE, Breipohl W, Lincoln DT, Garcia-Aragon J, Waters MJ, 1990 Localization of the growth hormone receptor/binding protein in skin. J Endocrinol 126: 467471.

32. Simard M, Manthos H, Giaid A, Lefebvre Y, Goodyer CG, 1996 Ontogeny of growth hormone receptors in human tissues: an immunohistochemical study. J Clin Endocrinol Metab 81: 3097-3102.

33. Serres M, Viac J, Schmitt D, 1996 Glucocorticoid receptor localization in human epidermal cells. Arch Dermatol Res 288: 140-146.

34. Leiferman KM, Schroeter A, Kirschner MK, Spelsberg TC, 1983 Characterization of the glucocorticoid receptor in human skin. J Invest Dermatol 81: 355-361.

35. Liang T, Hoyer S, Yu R, et al, 1993 Immunocytochemical localization of androgen receptors in human skin using monoclonal antibodies against the androgen receptor. J Invest Dermatol 100: 663-666.

36. Tadokoro T, Itami S, Hosokawa K, Terashi H, Takayasu S, 1997 Human genital melanocytes as androgen target cells. J Invest Dermatol 109: 513-517.

37. Lachgar S, Charveron M, Sarraute J, Mourard M, Gall Y, Bonafe JL, 1999 In vitro main pathways of steroid action in cultured hair follicle cells: vascular approach. J Investig Dermatol Symp Proc 4: 290-295.

38. Im S, Lee ES, Kim W, et al, 2000 Expression of progesterone receptor in human keratinocytes. J Korean Med Sci 15: 647-654.

39. Oikarinen A, Oikarinen H, Meeker CA, Tan EM, Uitto J, 1987 Glucocorticoid receptors in cultured human skin fibroblasts: evidence for down-regulation of receptor by glucocorticoid hormone. Acta Derm Venereol 67: 461468 .

40. Gad YZ, Berkovitz GD, Migeon CJ, Brown TR, 1988 Studies of up-regulation of androgen receptors in genital skin fibroblasts. Mol Cell Endocrinol 57: 205-213.

41. Fimmel S, Saborowski A, Terouanne B, Sultan C, Zouboulis ChC, 2003 Antisense-oligonucleotides inhibit androgen receptor expression and biological activity in epithelial skin cells. J Invest Dermatol 121: Abstract 0502. 42. Törmä H, Rollman O, Vahlquist A, 1993 Detection of mRNA transcripts for retinoic acid, vitamin D3, and thyroid hormone(c-erb-A) nuclear receptors in human skin using reverse transcription and polymerase chain reaction. Acta Derm Venereol 73: 102-107.

43. Zonefrati R, Rotella CM, Toccafondi RS, Arcangeli P, 1983 Thyroid hormone receptors in human cultured fibroblasts: evidence for cellular T4 transport and nuclear T3 binding. Horm Metab Res 15: 151-154.

44. Thornton MJ, Taylor AH, Mulligan K, et al, 2003 Oestrogen receptor-b is the predominant oestrogen receptor in human scalp skin. Exp Dermatol 12: 181-190.

45. Crandall DL, Busler DE, Novak TJ, Weber RV, Kral JG, 1998 Identification of estrogen receptor beta RNA in human breast and abdominal subcutaneous adipose tissue. Biochem Biophys Res Commun 248: 523-526.

46. Jee SH, Lee SY, Chiu HC, Chang CC, Chen TJ, 1994 Effects of estrogen and estrogen receptor in normal human melanocytes. Biochem Biophys Res Commun 199: 14071412.

47. Haczynski J, Tarkowski R, Jarzabek K, et al, $2002 \mathrm{Hu}-$ man cultured skin fibroblasts express estrogen receptor alpha and beta. Int J Mol Med 10: 149-153.

48. Reichrath J, Mittmann M, Kamradt J, Muller SM, 1997 Expression of retinoid-X receptors (-alpha,-beta,-gamma) and retinoic acid receptors (-alpha,-beta,-gamma) in normal human skin: an immunohistological evaluation. Histochem J 29: 127-133.

49. Siegenthaler G, Saurat J-H, 1991 Natural retinoids: metabolism and transport in human epidermal cells In Saurat J-H (ed) Retinoids: 10 years on, Basel: Karger; pp, 56-68.

50. Doran TI, Lucas DA, Levin AA, et al, 1991 Biochemical and retinoid receptor activities in human sebaceous cells In Saurat J-H (ed) Retinoids: 10 years on, Basel: Karger; pp, 243-253.

51. Tsukada M, Schröder M, Roos TC, et al, 2000 13-cis Retinoic acid exerts its specific activity on human sebocytes through selective intracellular isomerization to all-trans retinoic acid and binding to retinoid acid receptors. J Invest Dermatol 115: 321-327.

52. Reichrath J, Munssinger T, Kerber A, et al, 1995 In situ detection of retinoid-X receptor expression in normal and psoriatic human skin. Br J Dermatol 133: 168-175.

53. Milde P, Hauser U, Simon T, et al, 1991 Expression of 1,25-dihydroxyvitamin D3 receptors in normal and psoriatic skin. J Invest Dermatol 97: 230-239.

54. Reichrath J, Classen UG, Meineke V, et al, 2000 Immunoreactivity of six monoclonal antibodies directed against 1,25-dihydroxyvitamin-D3 receptors in human skin. Histochem J 32: 625-629.

55. Rosenfield RL, Deplewski D, Greene ME, 2000 Peroxisome proliferator-activated receptors and skin development. Horm Res 54: 269-274.

56. Chen W, Yang C-C, Sheu H-M, Seltmann H, Zouboulis ChC, 2003 Expression of peroxisome proliferator-activated receptor and CCAAT/enhancer binding protein tran- 
scription factors in cultured human sebocytes. J Invest Dermatol 121: 441-447.

57. Maioli E, Fortino V, Torricelli C, Arezzini B, Gardi C, 2002 Effect of parathyroid hormone-related protein on fibroblast proliferation and collagen metabolism in human skin. Exp Dermatol 11: 302-310.

58. Pun KK, Arnaud CD, Nissenson RA, 1988 Parathyroid hormone receptors in human dermal fibroblasts: structural and functional characterization. J Bone Miner Res 3: 453-460.

59. Quevedo ME, Slominski A, Pinto W, Wei E, Wortsman J, 2001 Pleiotropic effects of corticotropin releasing hormone on normal human skin keratinocytes. In Vitro Cell Dev Biol Anim 37: 50-54.

60. Thody AJ, 1999 alpha-MSH and the regulation of melanocyte function. Ann N Y Acad Sci 885: 217-229.

61. Orel L, Simon MM, Karlseder J, et al, $1997 \alpha$-Melanocyte-stimulating hormone down-regulates differentiationdriven heat shock protein 70 expression in keratinocytes. J Invest Dermatol 108: 401-405.

62. Böhm M, Schulte U, Kalden H, Luger TA, 1999 Alphamelanocyte-stimulating hormone modulates activation of NF-kB and AP-1 and secretion of interleulin-8 in human dermal fibroblasts. Ann NY Acad Sci 885: 277-286.

63. Kiss M, Wlaschek M, Brenneisen P, et al, 1995 a-Melanocyte stimulating hormone induces collagenase/matrix metalloproteinase-1 in human dermal fibroblasts. J Biol Chem 376: 425-430.

64. Teofoli P, Frezzolini A, Puddu P, De Pita O, Mauviel A, Lotti T, 1999 The role of proopiomelanocortin-derived peptides in skin fibroblast and mast cell functions. Ann N Y Acad Sci 885: 268-276.

65. Lotti T, Bianchi B, Ghersetich I, Brazzini B, Hercogova J, 2002 Can the brain inhibit inflammation generated in the skin? The lesson of gamma-melanocyte-stimulating hormone. Int J Dermatol 41: 311-318.

66. Bigliardi-Qi M, Bigliardi PL, Eberle AN, Bóchner S, Rufli T, 2000 beta-Endorphin stimulates cytokeratin 16 expression and downregulates $\mu$-opiate receptor expression in human epidermis. J Invest Dermatol 114: 527-532.

67. Haegerstrand A, Jonzon B, Dalsgaard CJ, Nilsson J, 1989 Vasoactive intestinal polypeptide stimulates cell proliferation and adenylate cyclase activity of cultured human keratinocytes. Proc Natl Acad Sci U S A 86: 5993-5996.

68. Kakurai M, Fujita N, Kiyosawa T, et al, 2002 Vasoactive intestinal peptide and cytokines enhance stem cell factor production from epidermal keratinocytes DJM-1. J Invest Dermatol 119: 1183-1188.

69. Seiffert K, Granstein RD, 2002 Neuropeptides and neuroendocrine hormones in ultraviolet radiation-induced immunosuppression. Methods 28: 97-103.

70. Seuwen K, Pouyssegur J, 1990 Serotonin as a growth factor. Biochem Pharmacol 39: 985-990.

71. Toyoda M, Nakamura M, Morohashi M, 2002 Neuropeptides and sebaceous glands. Eur J Dermatol 12: 422-427.

72. Toyoda M, Nakamura M, Makino T, Kagoura M, Morohashi M, 2002 Sebaceous glands in acne patients express high levels of neutral endopeptidase. Exp Dermatol 11:
241-247.

73. Deplewski D, Rosenfield RL, 1999 Growth hormone and insulin-like growth factors have different effects on sebaceous cell growth and differentiation. Endocrinology 140: 4089-4094.

74. Zouboulis ChC, Xia L, Akamatsu H, et al, 1998 The human sebocyte culture model provides new insights into development and management of seborrhoea and acne. Dermatology 196: 21-31.

75. Kuroda K, Utani A, Hamasaki Y, Shinkai H, 2001 Upregulation of putative hyaluronan synthase mRNA by basic fibroblast growth factor and insulin-like growth factor-1 in human skin fibroblasts. J Dermatol Sci 26: 156160.

76. Lemmey AB, Glassford J, Flick-Smith HC, Holly JM, Pell JM, 1997 Differential regulation of tissue insulin-like growth factor-binding protein (IGFBP)-3, IGF-I and IGF type 1 receptor mRNA levels, and serum IGF-I and IGFBP concentrations by growth hormone and IGF-I. J Endocrinol 154: 319-328.

77. Philpott MP, Sanders DA, Kealey T, 1996 Whole hair follicle culture. Dermatol Clin 14: 595-607.

78. Hermann M, Berger P, 2001 Hormonal changes in aging men: a therapeutic indication? Exp Gerontol 36: 10751082 .

79. Shulman DI, 2002 Metabolic effects of growth hormone in the child and adolescent. Curr Opin Pediatr 14: 432436.

80. Ahsan MK, Urano Y, Kato S, Oura H, Arase S, 1998 Immunohistochemical localization of thyroid hormone nuclear receptors in human hair follicles and in vitro effect of L-triidothyronine on cultured cells of hair follicles and skin. J Med Invest 44: 179-184.

81. Chen W, Zouboulis ChC, Fritsch M, et al, 1998 Evidence of heterogeneity and quantitative differences of the type $15 \alpha$-reductase expression in cultured human skin cells. Evidence of its presence in melanocytes. J Invest Dermatol 110: 84-89.

82. Chen W, Thiboutot D, Zouboulis ChC, 2002 Cutaneous androgen metabolism: basic research and clinical perspectives. J Invest Dermatol 119: 992-1007.

83. Akamatsu H, Zouboulis ChC, Orfanos CE, 1992 Control of human sebocyte proliferation in vitro by testosterone and 5-alpha-dihydrotestosterone is dependent on the localization of the sebaceous glands. J Invest Dermatol 99: 509-511.

84. Akamatsu H, Zouboulis ChC, Orfanos CE, 1993 Spironolactone directly inhibits proliferation of cultured human facial sebocytes and acts antagonistically to testosterone and 5-alpha-dihydrotestosterone in vitro. J Invest Dermatol 100: 660-662.

85. Zouboulis ChC, Seltmann H, Neitzel H, Orfanos CE, 1999 Establishment and characterization of an immortalized human sebaceous gland cell line (SZ95). J Invest Dermatol 113: 1011-1020.

86. Itami S, Kurata S, Sonoda T, Takayasu S, 1991 Mechanism of action of androgens in dermal papilla cells. Ann NY Acad Sci 642: 385-395. 
87. Zouboulis ChC, Akamatsu H, Stephanek K, Orfanos CE, 1994 Androgens affect the activity of human sebocytes in culture in a manner dependent on the localization of the sebaceous glands and their effect is antagonized by spironolactone. Skin Pharmacol 7: 33-40.

88. Rosenfield RL, Deplewski D, Kentsis A, Ciletti N, 1998 Mechanisms of androgen induction of sebocyte differentiation. Dermatology 196: 43-46.

89. Wrobel A, Mandt N, Hossini A, et al, $20005 \alpha$-Dihydrotestosterone and testosterone induce apoptosis in human dermal papilla cells by downregulation of the bcl-2 pathway. J Invest Dermatol 115: 581.

90. Kao JS, Garg A, Mao-Qiang M, et al, 2001 Testosterone perturbs epidermal permeability barrier homeostasis. J Invest Dermatol 116: 443-451.

91. Thornton MJ, 2002 The biological actions of estrogens on skin. Exp Dermatol 11: 487-502.

92. Brincat MP, 2000 Hormone replacement therapy and the skin. Maturitas 29: 107-117.

93. Punnonen R, 1972 Effect of castration and peroral estrogen therapy on the skin. Acta Obstet Gynecol Scand 21: 3-44.

94. Hoffmann R, Niiyama S, Huth A, Kissling S, Happle R, $200217 \alpha$-estradiol induces aromatase activity in intact human anagen hair follicles ex vivo. Exp Dermatol 11: 376-380.

95. Kanda N, Watanabe S, 2003 17 $\beta$-estradiol inhibits the production of RANTES in human keratinocytes. J Invest Dermatol 120: 420-427.

96. Kanda N, Watanabe S, 2003 17 $\beta$-estradiol inhibits the production of interferon-induced protein of $10 \mathrm{kDa}$ by human keratinocytes. J Invest Dermatol 120: 411-419.

97. Guy R, Ridden C, Kealey T, 1996 The improved organ maintenance of the human sebaceous gland: modeling in vitro the effects of epidermal growth factor, androgens, estrogens, 13-cis retinoic acid, and phenol red. J Invest Dermatol 106: 454-460.

98. Jee SH, Lee SY, Chiu HC, Chang CC, Chen TJ, 1994 Effects of estrogen and estrogen receptor in normal human melanocytes. Biochem Biophys Res Commun 199: 14071412.

99. Calkin AC, Sudhir K, Honisett S, Williams MR, Dawood T, Komesaroff PA, 2002 Rapid potentiation of endothelium-dependent vasodilation by estradiol in postmenopausal women is mediated via cyclooxygenase 2. J Clin Endocrinol Metab 87: 5072-5075.

100. Makrantonaki E, Oeff MK, Fimmel S, Zouboulis ChC, 2003 Molecular mechanisms of hormone-induced skin aging. Exp Dermatol 12: 333.

101. Stratakis CA, Mastorakos G, Mitsiades NS, Mitsiades CS, Chrousos GP, 1998 Skin manifesttations of Cushing disease in children and adolescents before and after the resolution of hypercortisolemia. Pediatr Dermatol 15: 253258.

102. Gysler A, Lange K, Korting HC, Schäfer-Korting M, 1997 Prednicarbate biotransformation in human foreskin keratinocytes and fibroblasts. Pharm Res 14: 793-797.

103. Radoja N, Komine M, Jho SH, Blumenberg M, Tomic-
Canic M, 2000 Novel mechanism of steroid action in skin through glucocorticoid receptor monomers. Mol Cell Biol 20: 4328-4339.

104. Zouboulis ChC, Seltmann H, Sass JO, et al, 1999 Retinoid signaling by all-trans retinoic acid and all-trans retinoyl- $\beta-\Delta$-glucuronide is attenuated by simultaneous exposure of human keratinocytes to retinol. J Invest Dermatol 112: $157-164$.

105. Randolph RK, Simon M, 1997 Metabolism of all-transretinoic acid by cultured human epidermal keratinocytes. J Lipid Res 38: 1374-1383.

106. Zouboulis ChC, Orfanos CE 2000 Retinoids In Millikan LE (ed) Drug Therapy in Dermatology, New York Basel: Marcel Dekker, pp, 171-233.

107. Zouboulis ChC, Korge B, Akamatsu H, et al, 1991 Effects of 13-cis-retinoic acid, all-trans-retinoic acid and acitretin on the proliferation, lipid synthesis and keratin expression of cultured human sebocytes in vitro. J Invest Dermatol 96: 792-797.

108. Zouboulis ChC, Korge BP, Mischke D, Orfanos CE, 1993 Altered proliferation, synthetic activity, and differentiation of cultured human sebocytes in the absence of vitamin A and their modulation by synthetic retinoids. J Invest Dermatol 101: 628-633.

109. Schuessler M, Astecker N, Herzig G, Vorisek G, Schuster I, 2001 Skin is an autonomous organ in synthesis, twostep activation and degradation of vitamin D(3): CYP27 in epidermis completes the set of essential vitamin $\mathrm{D}(3)$ hydroxylases. Steroids 66: 399-408.

110. Garach-Jehoshua O, Ravid A, Liberman UA, Koren R, 1999 1,25-Dihydroxyvitamin D3 increases the growth-promoting activity of autocrine epidermal growth factor receptor ligands in keratinocytes. Endocrinology 140: 713721.

111. Hughes SV, Robinson E, Bland R, Lewis HM, Stewart PM, Hewison M, 1997 1,25-dihydroxyvitamin D3 regulates estrogen metabolism in cultured keratinocytes. Endocrinology 138: 3711-3718.

112. Gurlek A, Pittelkow MR, Kumar R, 2002 Modulation of growth factor/cytokine synthesis and signaling by $1 \mathrm{a}, 25$ dihydroxyvitamin $\mathrm{D}(3)$ : implications in cell growth and differentiation. Endocr Rev 23: 763-786.

113. Oyama N, Iwatsuki K, Satoh M, Akiba H, Kaneko F, 2000 Dermal fibroblasts are one of the therapeutic targets for topical application of 1alpha, 25-dihydroxyvitamin D3: the possible involvement of transforming growth factor-beta induction. Br J Dermatol 143: 1140-1148.

114. Bollinger Bollag W, Bollag RJ, 2001 1,25-Dihydroxyvitamin $\mathrm{D}(3)$, phospholipase $\mathrm{D}$ and protein kinase $\mathrm{C}$ in keratinocyte differentiation. Mol Cell Endocrinol 177: 173182.

115. Ravid A, Rubinstein E, Gamady A, Rotem C, Liberman UA, Koren R, 2002 Vitamin D inhibits the activation of stress-activated protein kinases by physiological and environmental stresses in keratinocytes. J Endocrinol 173: 525-532.

116. Adorini L, 2002 Immunomodulatory effects of vitamin D receptor ligands in autoimmune diseases. Int Immunop- 
harmacol 2: 1017-1028.

117. Goren I, Pfeilschifter J, Frank S, 2003 Determination of leptin signaling pathways in human and murine keratinocytes. Biochem Biophys Res Commun 303: 1080-1085.

118. Artwohl M, Roden M, Holzenbein T, Freudenthaler A, Waldhausl W, Baumgartner-Parzer SM, 2002 Modulation by leptin of proliferation and apoptosis in vascular endothelial cells. Int J Obes Relat Metab Disord 26: 577580.

119. Rivier M, Safonova I, Lebrun P, Griffiths CE, Ailhaud G, Michel S, 1998 Differential expression of peroxisome proliferator-activated receptor subtypes during the differentiation of human keratinocytes. J Invest Dermatol 111: 1116-1121.

120. Westergaard M, Henningsen J, Svendsen ML, et al, 2001 Modulation of keratinocyte gene expression and differentiation by PPAR-selective ligands and tetradecylthioacetic acid. J Invest Dermatol 116: 702-712.

121. Ellis CN, Varani J, Fisher GJ, et al, 2000 Troglitazone improves psoriasis and normalizes models of proliferative skin disease: ligands for peroxisome proliferator-activated receptor-gamma inhibit keratinocyte proliferation. Arch Dermatol 136: 609-616.

122. Thiboutot DM, Gilliland KL, Sivarajah S, Cong Z, 2000 Peroxisome proliferator-activated receptor (PPAR) expression in human sebaceous glands. J Invest Dermatol 114: 810.

123. Street T, Holland DB, Meyers N, Cunliffe WJ, Randall VA, $2000 \operatorname{PPAR} \gamma$ (peroxisome proliferator-activated receptor- $\gamma$ ) is present in sebaceous glands from normal and acne patient human skin. Horm Res 53: 95.

124. Seltmann H, Hornemann S, Orfanos CE, Zouboulis ChC, 1999 Linoleic acid induces accumulation of neutral lipids in undifferentiated human sebocytes and reduces spontaneous IL-8 secretion. Arch Dermatol Res 291: 181.

125. Ma H, Sprecher HW, Kolattukudy PE, 1998 Estrogeninduced production of a peroxisome proliferator-activated receptor (PPAR) ligand in a PPAR $\gamma$-expressing tissue. J Biol Chem 273: 30131-30138.

126. Ingham E, Eady EA, Goodwin CE, Cove JH, Cunliffe WJ, 1992 Pro-inflammatory levels of interleukin-1 alpha-like bioactivity are present in the majority of open comedones in acne vulgaris. J Invest Dermatol 98: 895-901.

127. Ingham E, Walters CE, Eady EA, Cove JH, Kearney JN, Cunliffe WJ, 1998 Inflammation in acne vulgaris: failure of skin micro-organisms to modulate keratinocyte interleukin 1 alpha production in vitro. Dermatology 196: 8688.

128. Boehm KD, Yun JK, Strohl KP, Elmets CA, 1995 Messenger RNAs for the multifunctional cytokines interleukin-1 alpha, interleukin-1 beta and tumor necrosis factor-alpha are present in adnexal tissues and in dermis of normal human skin. Exp Dermatol 4: 335-341.

129. Kang-Rotondo CH, Miller CC, Morrison AR, Pentland AP, 1993 Enhanced keratinocyte prostaglandin synthesis after UV injury is due to increased phospholipase activity. Am J Physiol 264: C396-C401.

130. Alestas T, Chen W, Zouboulis ChC, 2003 Arachidonic acid activates the leukotriene inflammatory signaling pathway in SZ95 sebocytes in vitro. Arch Dermatol Res 295: 490.

131. Devchand PR, Keller H, Peters JM, Vazquez M, Gonzalez FJ, Wahli W, 1996 The PPARalpha-leukotriene B4 pathway to inflammation control. Nature 384: 39-43.

132. Lin Q, Ruuska SE, Shaw NS, Dong D, Noy N, 1999 Ligand selectivity of the peroxisome proliferator-activated receptor alpha. Biochemistry 38: 185-190.

133. Alestas T, Chen WC, Zouboulis ChC, 2003 A possible role of LTB4 as a ligand of peroxisome proliferator-activated receptors (PPARs) in human skin inflammation. Exp Dermatol 12: 334.

134. Shappell SB, Gupta RA, Manning S, et al, 2001 15S-Hydroxyeicosatetraenoic acid activates peroxisome proliferator-activated receptor gamma and inhibits proliferation in PC3 prostate carcinoma cells. Cancer Res 61: 497503.

135. Shappell SB, Keeney DS, Zhang J, Page R, Olson SJ, Brash AR, 2001 15-Lipoxygenase-2 expression in benign and neoplastic sebaceous glands and other cutaneous adnexa. J Invest Dermatol 117: 36-43.

136. Zouboulis ChC, Nestoris S, Adler YD, et al, 2003 A new concept for acne therapy: a pilot study with zileuton, an oral 5-lipoxygenase inhibitor. Arch Dermatol 139: 668670.

137. Sharpe GR, Dillon JP, Durham B, Gallagher JA, Fraser WD, 1998 Human keratinocytes express transcripts for three isoforms of parathyroid hormone-related protein (PTHrP), but not for the parathyroid hormone/PTHrP receptor: effects of 1,25(OH)2 vitamin D3. Br J Dermatol 138: 944-951.

138. Kageshita T, Ishihara T, Tokuo H, et al, 2003 Widespread expression of parathyroid hormone-related peptide in melanocytic cells. Br J Dermatol 148: 533-538.

139. Slominski A, Wortsman J, Pisarchik A, et al, 2001 Cutaneous expression of corticotropin-releasing hormone (CRH), urocortin, and CRH receptors. FASEB J 15: 16781693.

140. Scholzen TE, Brzoska T, Kalden DH, et al, 1999 Expression of functional melanocortin receptors and proopiomelanocortin peptides by human dermal microvascular endothelial cells. Ann N Y Acad Sci 885: 239-253.

141. Richards RG, Hartman SM, 1996 Human dermal fibroblast cells express prolactin in vitro. J Invest Dermatol 106: $1250-1255$

142. Slominski A, Malarkey WB, Wortsman J, Asa SL, Carlson A, 2000 Human skin expresses growth hormone but not the prolactin gene. J Lab Clin Med 136: 476-481.

143. Schallreuter KU, Wood JM, Pittelkow MR, et al, 1996 Increased monoamine oxidase A activity in the epidermis of patients with vitiligo. Arch Dermatol Res 288: 1418.

144. Rudman SM, Philpott MP, Thomas GA, Kealey T, 1997 The role of IGF-I in human skin and its appendages: morphogen as well as mitogen? J Invest Dermatol 109: 770-777.

145. Barreca A, Larizza D, Damonte G, et al, 1997 Insulinlike growth factors (IGF-I and IGF-II) and IGF-binding 
protein-3 production by fibroblasts of patients with Turner's syndrome in culture. J Clin Endocrinol Metab 82: 1041-1046.

146. Lemmey AB, Glassford J, Flick-Smith HC, Holly JM, Pell JM, 1997 Differential regulation of tissue insulin-like growth factor-binding protein (IGFBP)-3, IGF-I and IGF type 1 receptor mRNA levels, and serum IGF-I and IGFBP concentrations by growth hormone and IGF-I. J Endocrinol 154: 319-328.

147. Proksch E, Feingold KR, Elias PM, 1992 Epidermal HMG CoA reductase activity in essential fatty acid deficiency: Barrier requirements rather than eicosanoid generation regulate cholesterol synthesis. J Invest Dermatol 99: 216220.

148. Cassidy DM, Lee CM, Laker MF, Kealey T, 1986 Lipogenesis in isolated human sebaceous glands. FEBS Lett 200: 173-176.

149. Thiboutot D, Jabara S, McAllister JM, et al, 2003 Human skin is a steroidogenic tissue: steroidogenic enzymes and cofactors are expressed in epidermis, normal sebocytes, and an immortalized sebocyte cell line (SEB-1). J Invest Dermatol 120: 905-914.

150. Kang S, Duell EA, Fisher GJ, et al, 1995 Application of retinol to human skin in vivo induces epidermal hyperplasia and cellular retinoid binding proteins characteristic of retinoic acid but without measurable retinoic acid levels or irritation. J Invest Dermatol 105: 549-556.

151. Kurlandsky SB, Xiao J-H, Duell EA, Voorhees JJ, Fisher GJ, 1994 Biological activity of all-trans-retinol requires metabolic conversion to all-trans-retinoic acid and is mediated through activation of nuclear receptors in human keratinocytes. J Biol Chem 269: 32821-32827.

152. Schuessler M, Astecker N, Herzig G, Vorisek G, Schuster I, 2001 Skin is an autonomous organ in synthesis, twostep activation and degradation of vitamin D(3): CYP27 in epidermis completes the set of essential vitamin $\mathrm{D}(3)$ hydroxylases. Steroids 66: 399-408.
153. Lehmann B, Knuschke P, Meurer M, 2000 A novel pathway for hormonally active calcitriol. Horm Res 54: 312315 .

154. Sjursen W, Brekke OL, Johansen B, 2000 Secretory and cytosolic phospholipase $\mathrm{A}(2)$ regulate the long-term cytokine-induced eicosanoid production in human keratinocytes. Cytokine 12: 1189-1194.

155. Miller W, Straus J, 1999 Molecular pathology and mechanism of action of the steroidogenic acute regulatory protein, StAR. J Steroid Biochem Mol Biol 69: 131-141.

156. Hoffmann R, Rot A, Niiyama S, Billich A, 2001 Steroid sulfatase in the human hair follicle concentrates in the dermal papilla. J Invest Dermatol 117: 1342-1348.

157. Hoffmann R, 2003 Steroidogenic isoenzymes in human hair and their potential role in androgenetic alopecia. Dermatology 206: 85-95.

158. Brodie A, Inkster S, Yue W, 2001 Aromatase expression in the human male. Mol Cell Endocrinol 178: 23-28.

159. Billich A, Rot A, Lam C, Schmidt JB, Schuster I, 2000 Immunohistochemical localization of steroid sulfatase in acne lesions: Implications for the contribution of dehydroepiandrosterone silfate to the pathogenesis of acne. Hormone Res 53: 99.

160. Duell EA, Eström A, Griffiths CEM, Chambon P, Voorhees JJ, 1992 Human skin levels of retinoic acid and cytochrome P-450-derived 4-hydroxyretinoic acid after topical application of retinoic acid in vivo compared to concentrations required to stimulate retinoic acid receptor-mediated transcription in vitro. J Clin Invest 90: 12691274.

161. Rollman O, Wood EJ, Olsson MJ, Cunliffe WJ, 1993 Biosynthesis of 3,4-didehydroretinol from retinol by human skin keratinocytes in culture. Biochem J 293: 675-682.

162. Cao T, Tsai SY, O'Malley BW, Wang XJ, Roop DR, 2002 The epidermis as a bioreactor: topically regulated cutaneous delivery into the circulation. Hum Gene Ther 13: 1075-1080. 